\title{
Vertical distribution of benthic ciliates in response to the oxygen concentration in an intertidal North Sea sediment
}

\author{
Ulrike-G. Berninger ${ }^{1}$, Slava S. Epstein ${ }^{2, *}$ \\ 'Max-Planck Institute for Marine Microbiology, Microsensor Group, Fahrenheitstr. 1, D-28359 Bremen, Germany \\ ${ }^{2}$ Marine Science Center, Northeastern University, East Point, Nahant, Massachusetts 01908, USA
}

\begin{abstract}
We investigated the vertical distribution of benthic ciliates in response to changes in the oxygen conditions in an intertidal North Sea sediment. Sediment samples originating from a sandy flat were placed in a small temperature-controlled seawater flow-through system in the laboratory. Oxygen concentrations in the sediment were manipulated by enhancing or repressing photosynthetic activity of sediment diatoms and cyanobacteria by varying light intensities in 3 parallel setups (continuous darkness, permanent light intensity of $400 \mu \mathrm{E} \mathrm{m}^{-2} \mathrm{~s}^{-1}$, and $7 \mathrm{~h}$ light and $7 \mathrm{~h}$ dark switch). Oxygen profiles were measured employing high resolution electrochemical oxygen microsensors. Simultaneously, small sediment cores were collected from the respective treatments, and divided into 1 or $2 \mathrm{~mm}$ thin slices. The ciliates from each vertical layer were identified and enumerated employing the quantitative protargol stain method. The ciliate community could be divided into 2 distinct groups. Epibenthic ciliates remained close to the sediment surface at all times and were rarely found in anoxic layers. In contrast, the majority of the ciliates adapted to an interstitial life style were almost always found in anoxic sediment layers and appeared to migrate away from high oxygen concentrations. There may be some strictly anaerobic ciliates among the ciliate assemblage; however, most of the ciliates we found and describe are microaerophilic and therefore rely on a permanent access to oxygen. The potential implications of these findings for the nutrient cycling across the oxic/anoxic boundary within sediments are discussed in light of possible limitations of the employed techniques.
\end{abstract}

KEY WORDS: Benthic ciliates - Oxygen - Vertical distribution

\section{INTRODUCTION}

The significance of protists for the flow of matter and nutrients through planktonic communities has been well documented (Azam et al. 1983, Berninger et al. 1993, Sherr \& Sherr 1994). High species diversities and densities reaching $10^{3}$ ciliates $\mathrm{cm}^{-3}$ of marine sediment and of up to $10^{6}$ flagellates $\mathrm{cm}^{-3}$ suggest that protists may be equally important for the dynamics of benthic ecosystems (Fenchel 1969, Hartwig 1973, Alongi 1986. Bak \& Nieuwland 1989, Patterson et al. 1989). Heterotrophic and mixotrophic benthic protists may play a major role as both consumers and producers of organic matter in sediments (Epstein et al. 1992, Hondeveld et al. 1992, Starink et al. 1994).

-Addressee for correspondence.

E-mail: sepstein@lynx.dac.neu.edu
Shallow marine sediments harbor large populations of autotrophic microorganisms, such as cyanobacteria, diatoms and pigmented flagellates, that release oxygen into the interstitial water. The application of electrochemical oxygen microsensors, which allow the measurement of chemical profiles at a resolution as fine as 50 to $100 \mu \mathrm{m}$ with minimal disturbance of the system (Revsbech \& Jørgensen 1986), has revealed that the sediment layer in which free oxygen is available is often confined to no more than the upper few $\mathrm{mm}$, despite high oxygen production at the sediment surface (Revsbech 1989). The oxygen penetration depth and the shape of its profile vary according to light availability and time of the day (Kühl et al. 1994). Studies of benthic protists have shown, however, that these organisms inhabit a much wider layer than the oxygenated part of the sediment (Burkovsky 1968, Fenchel 1969, Santangelo \& Lucchesi 1995), with re- 
ported population maxima in the top 1 to $2 \mathrm{~cm}$ of the sediment or deeper. This finding implies that many ciliates are able to live in anoxic environments. Interestingly, only a few ciliate species are confirmed anaerobes, while a much larger proportion are known to be microaerophilic forms. The occurrence of one of the major groups of benthic organisms in anoxic rather than oxic sediment layers may change some of our views on the organization of benthic communities and on the flux of organic matter and nutrients across the oxic/anoxic boundary.

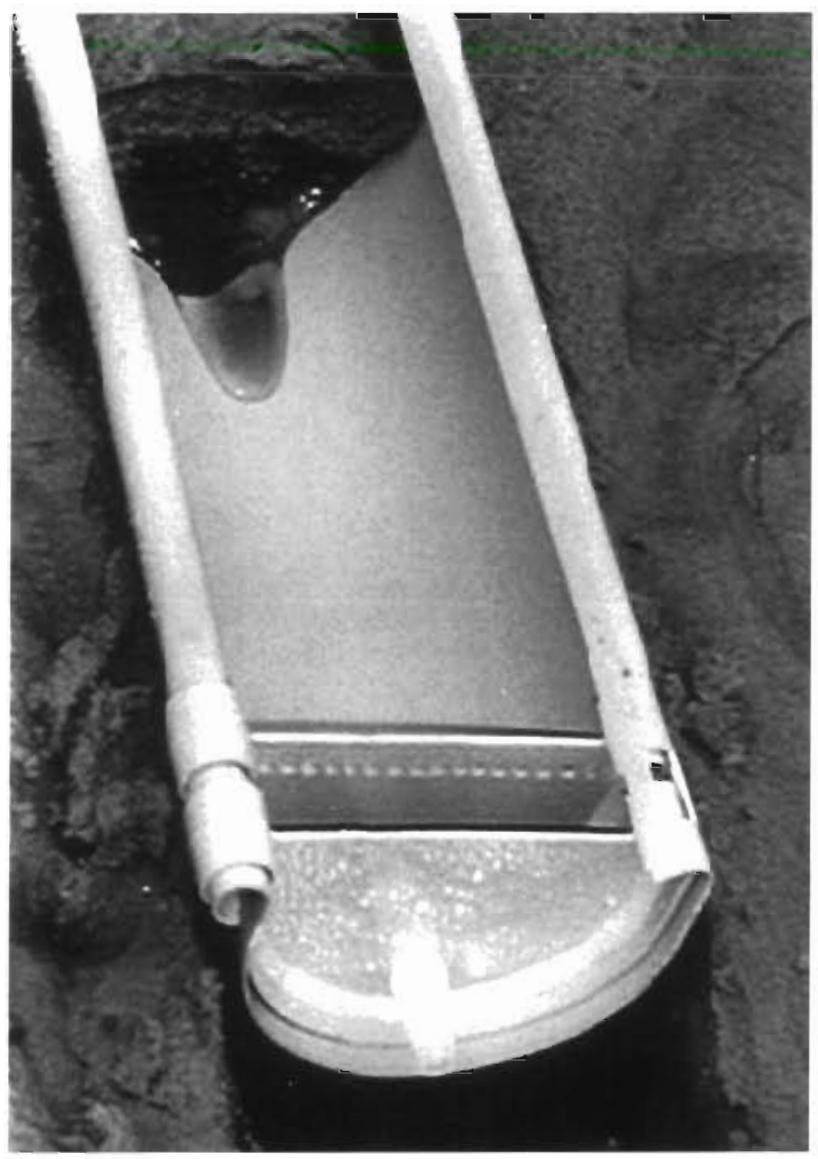

Fig. 1 PVC trough used to collect undisturbed sediment samples. Distal end (not shown) is open and is being slid into the sediment. Proximal end is equipped with 2 removable lids. The outer lid has a connector that, upon return to the laboratory, is connected to the seawater flow-through system. This transforms the sampling device into a flume channel without any additional sample transfer. The seawater first fills the chamber between the 2 lids and enters the sediment-containing part of the trough through a number of small holes in the inner lid. These holes make the water flow over the sediment surface in a nearly laminar fashion. Water leaves the trough through a combination of 2 lids and an intermediate chamber analogous to the one at the proximal end. These lids are installed in the field immediately upon sediment collection
We carried out an investigation of the vertical distribution of marine benthic ciliates with respect to the oxygen dynamics in a marine sandy tidal flat community. We manipulated the oxygen profiles in sediment cores placed in a small laboratory flow-through system by varying the illumination, thereby enhancing or repressing photosynthetic activity. We then examined the vertical distribution of ciliates to determine how protists responded to changing light and oxygen conditions in the sediment.

\section{MATERIAL AND METHODS}

Sampling procedure and experimental set-up. Sediments were collected on Scptcmber 1, 1993, from a sandy tidal flat of the North Sea near Cuxhaven, Germany, during low tide, ca $30 \mathrm{~m}$ from the beach. Air and sediment temperature were 15 and $14^{\circ} \mathrm{C}$, respectively; salinity was $20 \%$

PVC troughs, in a form of open half-cylinders made out of household gutters, served as both sampling devices and flume channels. The troughs were $50 \mathrm{~cm}$ long, $10 \mathrm{~cm}$ deep in the center and $14 \mathrm{~cm}$ wide at the top, and could be sealed at both ends with removable plastic lids. To collect field samples, 6 troughs were pushed horizontally into the sediment, carefully lifted up when filled, and closed (Fig. 1). This procedure kept disturbance and pore water loss at a minimum. The sediment surface was ca $4 \mathrm{~cm}$ below the upper edge of the troughs. In the laboratory the troughs were inserted into a pump-aided seawater recirculation system and filled with water that was collected simultaneously with the sediment cores. The water temperature was kept constant at $13^{\circ} \mathrm{C}$ with a Julabo cooling unit, and the water was continually aerated. The flow was adjusted to a velocity of $2 \mathrm{~cm} \mathrm{~s}^{-1}$ For $2 \mathrm{wk}$ following sampling the 6 cores were subjected to the same light regime of $12 \mathrm{~h}$ darkness and $12 \mathrm{~h}$ low light intensity (ca $120 \mu \mathrm{E} \mathrm{m}^{-2} \mathrm{~s}^{-1}$ ). A noticeable population of diatoms and cyanobacteria developed on the sediment surface, and some topography formed as a result of the activity of macrofauna

Experimental design. In order to examine the response of benthic ciliates to changes in the oxygen dynamics in the sediment, we exposed the sediment cores to different light regimes. This influenced the photosynthetic activity of the autotrophs which in turn affected concentration and penetration depth of oxygen in the sediment.

Prior to conducting the experiment, all sediment cores were kept in complete darkness for $24 \mathrm{~h}$. Thereafter, the 6 troughs were divided into 3 sets each consisting of 2 troughs. Each set represented a different experimental treatment: 1 set was kept in complete 
darkness at all times (DC, dark control), the second set was exposed to permanent light $\left(400 \mu \mathrm{E} \mathrm{m} \mathrm{m}^{-2} \mathrm{~s}^{-1}\right.$, LC, light control), and the third pair of troughs was subjected to a light regime alternating between $7 \mathrm{~h}$ light $\left(400 \mu \mathrm{E} \mathrm{m}^{-2} \mathrm{~s}^{-1}\right)$ and $7 \mathrm{~h}$ darkness (DLDL).

At selected time points, oxygen profiles were measured at a vertical resolution of $100 \mu \mathrm{m}$, employing Clarke-type oxygen microelectrodes, following the description in Revsbech \& Jørgensen (1986). Immediately after taking of the oxygen profile, a small sediment core was extracted at the same location with a $60 \mathrm{ml}$ plastic syringe, Luer end cut off. The sites for oxygen measurements and sediment coring were at least $2 \mathrm{~cm}$ from the edge of the trough and lacked visible traces of macrofaunal activity. In the $\mathrm{LC}$ and DC treatments, the time points were scattered over the whole experimental period $(15 \mathrm{~h})$. In the DLDL treatments, the first measurement and sample were obtained in the dark period immediately before the light was switched on. The next time points were at $5,30,150$ and 400 min after the start of the illumination, at 5, 30, 150 and $400 \mathrm{~min}$ after switching the lights off again, and 5 min after the light had been turned on for a second light period. The time points indicated in Fig. 4 refer to the time of coring.

The sediment cores were immediately sectioned after gradual extrusion of the sample from the syringe with the help of a micrometer screw attached to the plunger (Joint et al. 1982). The top $5 \mathrm{~mm}$ was divided into $1 \mathrm{~mm}$ slices and the following $14 \mathrm{~mm}$ into $2 \mathrm{~mm}$ slices. There was no loss or displacement of pore water during the extrusion of the cores. Individual slices were placed into preweighed vials containing 30 or $40 \mathrm{ml}$ of Bouin's fixative mixture $(40 \%$ buffered formaldehyde saturated with picric acid and $2 \%$ glacial acetic acid) and mixed gently. All fixed samples were weighed to calculate the wet weight of the individual sediment slices and were stored refrigerated $\left(4^{\circ} \mathrm{C}\right)$ until further processing

Enumeration of ciliates. Ciliates were extracted using a modification of the procedure of Bak \& Nieuwland (1989). In order to separate the protists from sediment particles, each sample was carefully resuspended, allowed to settle for 10 to $15 \mathrm{~s}$, and the supernatant collected. This washing procedure was repeated twice and all 3 supernatant fractions were combined. For each sample, a known fraction $(1 / 2$ the volume in the case of $1 \mathrm{~mm}$ slices, and $1 / 4$ in the case of $2 \mathrm{~mm}$ slices) of the total supernatant was filtered onto a Millipore cellulose $3 \mu \mathrm{m}$ pore-size filter with negative pressure never exceeding $50 \mathrm{~mm} \mathrm{Hg}$. Subsequently, the filters were processed employing the quantitative protargol staining (QPS) technique (Montagnes \& Lynn 1987) resulting in permanent microscopic preparations. The filters were scanned at $156 \times$ magnification on either a Zeiss Axiophot microscope equipped for phase contrast microscopy or on a Zeiss standard microscope equipped for Nomarsky DIC microscopy. Ciliates were identified after Carey (1992) at $750 \times$ to $1850 \times$ magnification and counted.

Profiles of ciliate vertical distribution were reconstructed based on their abundance in the examined horizons. To characterize each profile by a single parameter, we calculated its weighted mean depth $H$ (= the position of the population's center). This was done, upon normalization of the abundance data by a square-root transformation, by applying the formula:

$$
H=\frac{\sum_{i=1}^{12}\left(N_{i} \times h_{i}\right)}{\sum_{i=1}^{12} N_{i}}
$$

where $h$ and $N$ are the sample depth and ciliate abundance, respectively, in the sediment layer $i$.

We used standard statistical approaches to calculate means, linear regression coefficients and error margins, according to Sokal \& Rohlf (1981). To compare the depths of vertical distribution centers, we employed a Wilcoxon nonparametric test.

\section{RESULTS}

\section{Oxygen distribution in the sediment and its dynamics}

In both the DC and LC treatments, oxygen concentration, penetration depth and shape of the profile showed little within-treatment variation over time (Fig. 2). In the DC treatment, the oxygen concentration in the sediment was always lower than that in the water and decreased rapidly with increasing sediment depth. Penetration depth never exceeded $2.5 \mathrm{~mm}$ (mean $\pm \mathrm{SD}: 2.1 \pm 0.2 \mathrm{~mm}$ ). In the LC treatment, oxygen penetrated down to a depth of $3.7 \mathrm{~mm}$ after $7 \mathrm{~h}$ of illumination. There was always a distinct subsurface peak of the oxygen concentration $(295.9 \pm 57.5 \mu \mathrm{mol}$ $\mathrm{O}_{2} \mathrm{I}^{-1}$ at $0.8 \pm 0.1 \mathrm{~mm}$ below the sediment surface).

The oxygen profiles in the DLDL treatment varied according to the light conditions (Fig. 2). The initial profile, taken at the end of the period of prolonged darkness, showed values almost identical to those of the DC treatment; oxygen penetration depth was $1.5 \mathrm{~mm}$. Within minutes of the onset of illumination a distinct oxygen profile formed in the sediment, characterized by a subsurface maximum (364.4 $\pm 92.4 \mu \mathrm{mol}$ $\mathrm{O}_{2} \mathrm{I}^{-1}$ at $0.7 \pm 0.2 \mathrm{~mm}$ sediment depth) and a penetration depth of up to $3.8 \mathrm{~mm}$. Upon shading the sediments, the oxygen profiles changed back to about the level described above for darkness. 


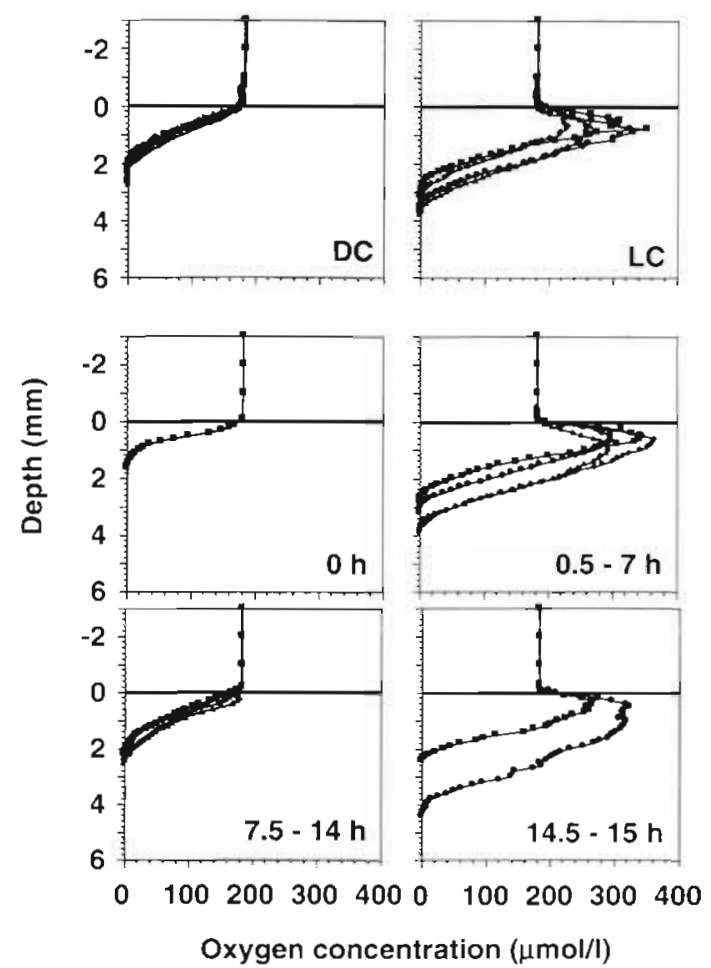

Fig. 2. Oxygen profiles in marine intertidal sediments. Sediment surface is at $0 \mathrm{~mm}$ depth. DC: dark control, LC: light control; time points in hours for DLDL treatment (see text for further details). Light and dark background shading indicate light and dark phases, respectively

\section{Composition of the benthic community}

The community we studied comprised the typical inhabitants of a sandy tidal flat, such as bacteria, including cyanobacteria, diatoms, aplastidic and plastidic nano- and microflagellates, ciliates, nematodes, harpacticoid copepods and other meiobenthic animals (Fenchel 1969). Macrofauna was present in the field and experimental communities, but the subcores taken for protists counts were from the areas of the main cores without macrofauna.

The ciliate community received special attention in our investigation. A total of 45 different ciliate species were identified; the mean abundance of the entire ciliate assemblage, averaged from all the samples collected, was 135 ind. $g$ ' wet sediment, which was within the range observed for other similar habitats (Fenchel 1969 , Hartwig 1973, Alongi 1986). The following 12 species represented numerically $>90 \%$ of the total ciliate assemblage and were observed in all samples: Coleps hirtus, Loxophyllum rostratum, L. setigerum, TracheIonema oligostriata, Tracheloraphis margaritatus, Tracheloraphis swedmarkii, Geleia orbis, Paraspathidium fuscum, Pleuronema marina, Psammocephalus sp., Euplotes crassus and E. trisulcatus. The feeding preferences of these species span the whole range of bacterivory, herbivory, carnivory and histophagy. The following quantitative analysis is based on the abundance and distribution of these dominant species.

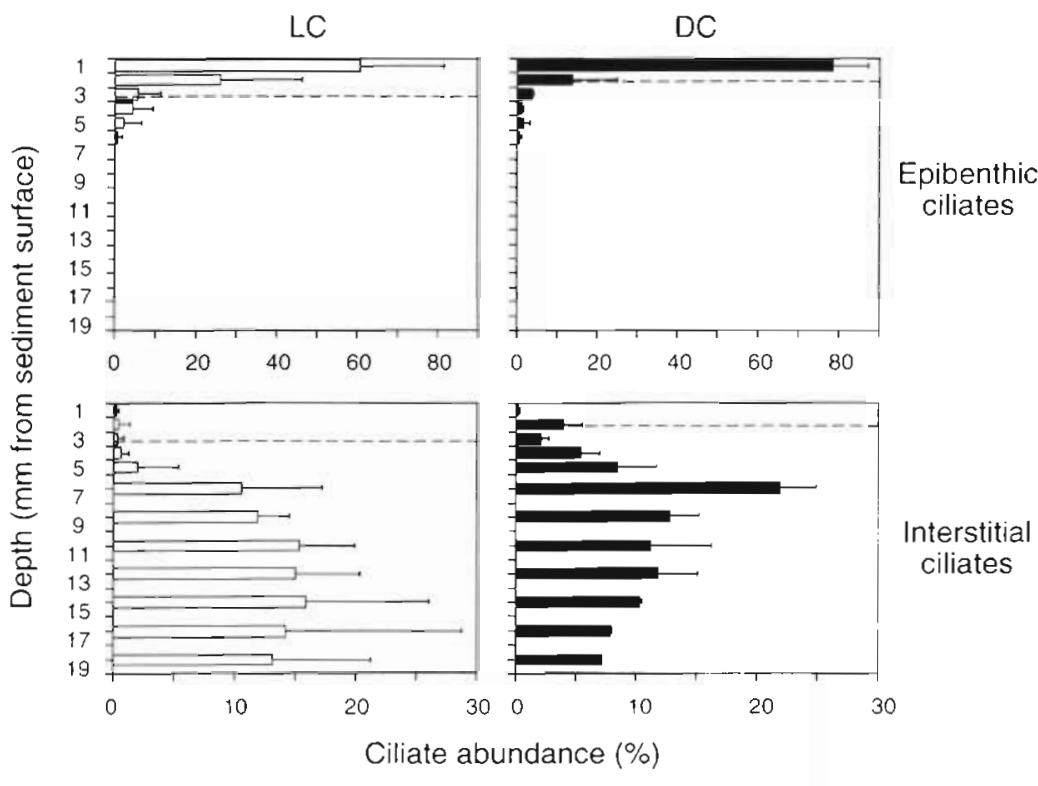

Fig. 3. Vertical distribution of epibenthic and interstitial ciliates in marine intertidal sediments incubated in small laboratory flumes. Data represent the average of 3 (LC) or 2 (DC) measurements ( $\pm 1 \mathrm{SE}$ ), respectively. Nole: depth intervals 1 to $5 \mathrm{~mm}$ represent densities obtained from sediment slices of $1 \mathrm{~mm}$ thickness, whereas the intervals below represent data obtained from $2 \mathrm{~mm}$ thick slices. Dotted line: oxygen penetration depth. Open bars: $L C_{\text {; }}$ filled bars: DC (see text for further explanation)

\section{Vertical distribution of ciliates in the sediment}

Among the 12 most common species, 2 distinct groups of epibenthic and interstitial ciliates (Patterson et al. 1989) could be differentiated. Epibenthic species (Euplotes crassus and E. trisulcatus, maximum abundance 400 ind. $\mathrm{g}^{-1}$ wet sediment or 410 ind $\mathrm{cm}^{-2}$ ) were confined to the sediment surface and the top $2 \mathrm{~mm}$ of the sediment at all light levels and at all times (Figs. $3 \& 4$ ). They showed no clear vertical migration pattern. Interstitial ciliates (the remaining 10 species) were distributed over a wider depth range but were absent from the sediment surface (Figs. 3 \& 4). Their maximum abundance was $250 \mathrm{ind} . \mathrm{g}^{-1}$ wet sediment or $1850 \mathrm{ind}$. $\mathrm{cm}^{-2}$.

The vertical distribution of interstitial ciliates varied under different illumination. The interstitial ciliates were found $2 \mathrm{~mm}$ deeper in the illuminated sediment 


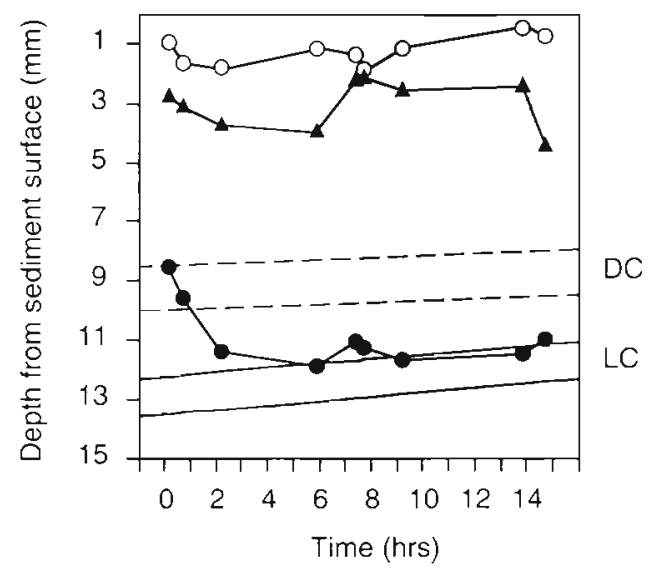

Fig. 4. Mean depth of vertical distribution of benthic ciliates during an incubation with alternating light regime. Dark periods indicated by dark background shading. (O) Epibenthic ciliates; ( $(\bullet)$ interstitial ciliates; $(\boldsymbol{\Delta})$ oxygen penetration depth. Dashed and solid lines: standard error intervals for linear regressions of the center of interstitial ciliate distribution in DC and LC, respectively

(LC treatment) than in the darkened cores (DC treatment; Fig. 3). The respective weighted mean ( \pm SE) depths of vertical distribution were $11.7 \pm 0.6 \mathrm{~mm}$ and $9.6 \pm 1.0 \mathrm{~mm}$ below the surface. This difference was statistically significant at the $p<0.05$ level.

At the beginning of the DLDL treatment the interstitial ciliates were distributed in essentially the same way as in the DC treatment (Figs. $3 \& 4$ ). After 7 h of illumination, their vertical distribution was very similar to that in the LC treatment. Over this period, the center of the vertical distribution of interstitial ciliates gradually shifted down by $3.1 \mathrm{~mm}$ (significant at the $\mathrm{p}<0.05$ level) while the oxygen penetration depth increased by $2.3 \mathrm{~mm}$ (Fig. 4). Thus, the scale of ciliate downward migration was comparable to the scale of the downward shift of the oxic/anoxic boundary. The $7 \mathrm{~h}$ long darkness that followed the first light period did not coincide with an upward migration of the ciliates back to their initial position. Instead, the center of their vertical distribution remained at or around the same depth that was reached during the light period. Individual ciliate species showed essentially the same pattern of vertical distribution.

\section{DISCUSSION}

Our results imply that the changing oxygen conditions in the sediment affect the vertical distribution of benthic ciliates. Epibenthic ciliates were found close to the sediment surface at all times. They did show some vertical migration but seemed to primarily exploit the oxygenated layer. In contrast, the more abundant interstitial ciliates appeared to avoid oxygen. Irrespective of the light conditions, the center of their vertical distribution was always below 8 to $9 \mathrm{~mm}$ depth, while the oxic/anoxic boundary was always above 4 to $5 \mathrm{~mm}$. This apparent avoidance reaction was also observed in the dynamics of the vertical distribution of interstitial ciliates: as the oxygen penetrated deeper into the sediment, the interstitial ciliates migrated downward in a remarkably proportional fashion (Fig. 4). These findings are similar to or consistent with the previous results whether they have been achieved by employing different (Fenchel 1969, Bak \& Nieuwland 1989, Alve \& Bernhard 1995) or almost identical methodology (detailed investigation of millimeter-scale ciliate vertical distribution with oxygen profiles measured by oxygen microelectrodes; Fenchel \& Bernard 1995).

Our results raise a number of interesting questions: (1) what are the mechanisms by which interstitial ciliates sense changes in oxygen concentration occurring several millimeters away from where they dwell; (2) how can organisms believed to be aerobes exist without direct access to oxygen; and (3) what are the ecological implications of our findings? For these questions we can at present offer only hypothetical answers.

(1) The rise of oxygen concentration in the uppermost sediment layer occurring as a result of illumination is likely to cause changes in the chemical environment not only in this top sediment horizon but in the underlying sediments as well. At the very least, the vertical profile of hydrogen sulfide should shift down as a result of deeper oxygen penetration. Therefore, the onset of illumination and the rise in oxygen concentration can be soon felt at depth where neither light nor oxygen are available. This may explain the apparent remote sensing of changes in light/oxygen conditions exhibited by interstitial ciliates.

(2) Only a small number of ciliates found in anoxic sediment layers are reported anaerobes; the majority of the recorded interstitial species are believed to have an aerobic metabolism. We can only speculate on how such ciliates can exist without a permanent supply of oxygen. High tolerance to anoxia by aerobic species has been reported (Finlay et al. 1991, Fenchel pers. comm.). It is also possible that some aerobic or microaerophilic ciliate species complement oxygen respiration with anaerobic metabolic pathways. For example, nitrate respiration under anoxia has been recorded for freshwater species of the genus Loxodes (Finlay 1985), a close relative of many interstitial ciliates present in our samples.

We believe that the majority of the interstitial ciliates we identified do not permanently inhabit sediment layers deplete of oxygen. We suggest that these ciliates migrate into oxygenated sediment layers, remain there 
for some time to obtain oxygen and then move back into the anoxic sediment. The vertical migration of benthic ciliates at the appropriate scale has been described earlier (Burkovsky et al. 1983); however, at this point we can offer only indirect supporting evidence for our hypotheses. Whereas the majority of the interstitial ciliates was always present well below the oxic/anoxic boundary, a small fraction of their populations could always be found in the oxygenated layer (Fig. 3). This fraction may have been constituted by occasional migrants. The rather small size of that fraction shows that these journeys must have been short and quickly followed by diving back into anoxia. This leaves the overall picture unaffected: the bulk of the ciliate assemblage was still located deep in the anoxic sediment throughout the experiment in all treatmenis.

(3) Such a migration would have significant ecological implications. For example, ciliate grazing and subsequent digestion may take place in different sediment layers. If ciliates feed on one side of the oxic/anoxic boundary and release nutrients on the other, there may be a transfer of organic matter and nutrients between the oxic and anoxic sediments mediated by protists.

If the majority of ciliates avoid oxygenated sediment layers, their grazing interactions with aerobic bacteria and active phototrophic organisms such as diatoms and cyanobacteria may be more limited than previously thought. Besides methodological reasons (Starink et al. 1994) this may in part explain why even abundant ciliate communities appear to consume only a small fraction of the production of diatoms (Epstein et al. 1992) and of the total bacterial production (Kemp 1988) in oxygenated sediments. In contrast, fermenting bacteria, nitrate reducers, sulfate reducers and other anaerobic bacteria would potentially be subjected to a grazing pressure many times greater than previously assumed since their predators may be recruited from both the oxic and anoxic sediment layers. The consequences of nutrient recycling mediated by grazing activity (Caron \& Goldman 1990) would in this scenario mostly benefit anaerobic rather than aerobic assemblages.

Our approaches have some potential shortcomings that deserve discussion. For example, oxygen concentration was not the sole variable in our experiments. Food availability, presence of predators, $\mathrm{H}_{2} \mathrm{~S}$ concentration and other factors potentially affecting ciliate behavior were not controlled during the experiments. In addition, we only investigated the ciliate community of the top $20 \mathrm{~mm}$ of the sediment. This may explain the low number of 'true' anaerobic ciliates in our samples. Protists are also found in deeper sediment layers where they may be subjected to constraints different to those characteristic of the surface. We cannot, therefore, extrapolate our theories over the entire sediment, but rather to a few $\mathrm{cm}$ close to the sediment/water interface.

Other potential limitations are related to oxygen measurements and ciliate enumeration. The position of the oxic/anoxic interface was determined assuming that the electrode ' 0 ' reading was indicative of the absence of oxygen. The sensitivity of oxygen microelectrodes has been shown to be between 0.15 and $1 \%$ of air saturation, or approximately 0.3 to $2 \mu \mathrm{M} \mathrm{O}_{2} \mathrm{l}^{-1}$ (Revsbech et al. 1980, Herbert 1992). Therefore, at the depth where the microelectrode would first give a reading of 0 , oxygen might still be present, and the thickness of the oxygenated sediment layer might thus be underestimated. However, the thickness of this missed part of the low-oxygen zone was likely to be insignificant. Fiting a parabola to the actual $\mathrm{O}_{2}$ profile (Rasmussen \& Jørgensen 1992) shows that such small quantities of oxygen would be consumed, whether biologically or chemically, within only few tenths of a millimeter of sediment. This consideration assumes a zero-order oxygen consumption kinetic. Although this model is likely to be an oversimplification (Rasmussen \& Jorgensen 1992, T. Fenchel pers. comm.), it repeatedly gave a close fit to the experimental data, whereas a first-order consumption kinetic model yielded far inferior results (Hofman et al. 1991, Rasmussen \& Jørgensen 1992). One can also infer negligible oxygen concentrations at or below the oxic/anoxic interface as determined by oxygen microelectodes from a strong increase in hydrogen sulfide concentrations at the depths where the electrode measures zero oxygen (Revsbech et al. 1980, Visscher et al. 1991).

It should also be noted that while the electrode readings may precisely identify the beginning of the anaerobic zone, they only do so at the point where the measurement was taken. Small pockets of oxygenated areas, for example caused by macrofaunal. burrowing and/or feeding activities (Aller \& Yingst 1985) or by pressure driven pore-water exchange (Hüttel \& Gust 1992), are scattered in the sediment and may be easily missed. We measured oxygen profiles in areas that did not show any disturbance by larger benthic organisms. Nevertheless, the sediment layers where we did not register any oxygen may be called anoxic only with an understanding of possible methodological limitations. It is in this sense that the terms such as 'anaerobic sediments' and 'oxic/anoxic interface' are used in the present study.

Furthermore, our work addresses ciliate migrations of a very small amplitude (few millimeters). The increment at which sediment cores were sectioned needed to be appropriately small, and the movement of interstitial water through the core during extrusion had to be prevented. The sampling protocol we adopted from Joint et al. (1982) met both these requirements. The 
size variation of individual sediment slices was under $15 \%$. Since the coring device was equipped with a plunger, no draining/displacement of the sample interstitial water was possible as that would have created vacuum in the syringe. The protocol we employed for ciliate enumeration (QPS) has a reported efficiency close to $100 \%$ (Bak \& Nieuwland 1989, Epstein unpubi.). As an identification protocol, it is highly recommended. Some delicate species might be undercounted (Montagnes \& Lynn 1987), but this should have been equal across light and dark treatments, thus not affecting the experimental outcome.

Therefore, limitations imposed by the employed methods do not invalidate the main conclusions of this paper. The majority of sediment ciliates were found below the oxic/anoxic interface. They may thus play an important role in the microbial dynamics of anoxic sediments. The dynamics of entire benthic microbial communities may depend more than previously thought on the processes taking place in anaerobic zones.

Acknowledgements. We are grateful to $M$. Hüttel and $O$. Görg for their advice on the design and construction of the experimental set-up, to A. Glud, G. Eickert and A. Eggers for the manufacturing of oxygen microelectrodes, and to $\mathrm{S}$. A. Wickham, M. Hütel, T Fenchel and C. Bernard for valuable comments on an earlier version of the manuscript. This research was supported in part by an MPI stipend and U.S. NSF grant OCE-9217250 to S.S.E. This is contribution no. 210 of the Marine Science Center of Northeastern University.

\section{LITERATURE CITED}

Aller RC, Yingst JY (1985) Effects of the marine deposit feeders Heteromastus filiformis (Polychaeta), Macoma baltica (Bivalvia), Tellina texana (Bivalvia) on averaged sedimentary solute transport, reaction rates, and microblal distributions. J mar Res 43:615-645

Alongi DM (1986) Quantitative estimates of benthic protozoa in tropical marine systems using silica gel: a comparison of methods. Estuar coast Shelf Sci 23:443-450

Alve E, Bernhard JM (1995) Vertical migratory response of benthic foraminifera to controlled oxygen concentrations in an experimental mesocosm. Mar Ecol Prog Ser 116: $137-151$

Azam F, Fenchel T, Field JG, Gray JS, Meyer-Reil LA, Thingstad $F$ (1983) The ecological role of water-column microbes in the sea. Mar Ecol Prog Ser 10:257-263

Bak RPM, Nieuwland G (1989) Seasonal fluctuations in benthic protozoan populations at different depths in marine sediments. Neth J Sea Res 24:37-44

Berninger UG, Wickham SA, Finlay BJ (1993) Trophic coupling withın the microbial food web: a study with fine temporal resolution in a eutrophic freshwater ecosystem. Freshwat Biol 30:419-432

Burkovsky IV (1968) Quantitative data on the vertical distribution of interstitial ciliates (Kandalaksha Bay, the White Sea). Zool Zh 47:1407-1410 (in Russian)

Burkovsky IV, Azovsky AI, Moliboga HH (1983) Daily vertical migrations of interstitial ciliates of the White Sea. Zool Zh 62:944-946 (in Russian)
Carey PG (1992) Marine interstitial ciliates. An illustrated key. Chapman \& Hall, London

Caron DA, Goldman JC (1990) Protozoan nutrient regeneration. In: Capriulo GM (ed) Ecology of marine protozoa. Oxford University Press, New York, p 283-306

Epstein SS, Burkovsky IV, Shiaris MP (1992) Ciliate grazing on bacteria, flagellates, and mucroalgae in a temperate zone sandy tidal flat: ingestion rates and food niche partitioning. J exp mar Biol Ecol 165:103-123

Fenchel I (1969) The ecology of marine microbenthos IV Structure and function of the benthic ecosystem, its chemical and physical factors and the microfauna communities with special reference to the ciliated protozoa. Ophelia 6: $1-182$

Fenchel T, Bernard C (1995) Behavioral responses in oxygen gradients of ciliates from microbial mats. Eur J Protistol 31 in press

Finlay BJ (1985) Nitrate respiration by protozoa (Loxodes spp.) in the hypolimnetic nitrite maximum of a productive freshwater pond. Freshwat Biol 15:333-346

Finlay BJ, Clarke KE, Vicente E, Miracle MR (1991) Anaerobic ciliates from a sulfide-rich solution lake in Spain. Eur $J$ Protistol 27:148-159

Hartwig E (1973) Die Ciliaten des Gezeiten-Sandstrandes der Nordseeinsel Sylt. In: Ax P (ed) Mikrofauna des Meeresbodens. Akademie der Wissenschaften und der Literatur, Göttingen, p 387-453

Herbert RA (1992) The application of microelectrodes in microbial ecology. J appl Bacteriol 73 (Suppl):164S-172S

Hofman PAG, de Jong SA, Wagenvoort EJ, Sandee AJJ (1991) Apparent sediment diffusion coefficients for oxygen and oxygen consumption rates measured with microelectrodes and bell jars: applications to oxygen budgets in estuarine intertidal sediments (Oosterschelde, SW Netherlands). Mar Ecol Prog Ser 69:261-272

Hondeveld BJM, Bak RPM, van Duyl FC (1992) Bacterivory by heterotrophic nanoflagellates in marine sediments measured by uptake of fluorescently labeled bacteria. Mar Ecol Prog Ser 89:63-71

Hüttel M, Gust G (1992) Impact of bioroughness on interfacial solute exchange in permeable sediments. Mar Ecol Prog Ser 89:253-267

Joint IR, Gee JM, Warwick RM (1982) Determination of finescale vertical distribution of microbes and meiofauna in an intertidal sediment. Mar Biol 72:157-164

Kemp PF (1988) Bacterivory by benthic ciliates: significance as a carbon source and impact on sediment bacteria. Mar Ecol Prog Ser 49:163-169

Kühl M, Lassen C, Jørgensen BB (1994) Light penetration and light intensity in sandy marine sediments measured with irradiance and scalar irradiance fiber-optic microprobes. Mar Ecol Prog Ser 105:139-148

Montagnes DJS, Lynn DH (1987) A quantitative protargol stain (QPS) for ciliates: method description and test of its quantitative nature. Mar Microb Food Webs 2: $83-93$

Patterson DJ, Larsen J, Corliss JO (1989) The ecology of heterotrophic flagellates and ciliates living in marine sediments. Prog Protistol 3:185-277

Rasmussen H, Jørgensen BB (1992) Microelectrode studies of seasonal oxygen uptake in a coastal sediment: role of molecular diffusion. Mar Ecol Prog Ser 81:289-303

Revsbech NP (1989) Diffusion characteristics of microbial communities determined by use of oxygen microsensors. J microbiol Meth 9:111-122

Revsbech NP, Jørgensen BB (1986) Microelectrodes: their use in microbial ecology. Adv microb Ecol 9:293-352 
Revsbech NP, Sørensen J, Blackburn TH, Lomholt JP (1980) Distribution of oxygen in marine sediments measured with microelectrodes. Limnol Oceanogr 25:403-411

Santangelo P, Lucchesi P (1995) Spatial distribution pattern of ciliated protozoa in a Mediterranean interstitial environment. Aquat microb Ecol 9:47-54

Sherr EB, Sherr BF (1994) Bacterivory and herbivory: key roles of phagotrophic protists in pelagic food webs. Microb Ecol 28:223-235

Sokal RR, Rohlf FJ (1981) Biometry. The principles and prac-

Responsible Subject Editor: T Fenchel, Helsingør, Denmark tice of statistics in biological research. WH Freeman \& Co, San Francisco

Starink M, Krylova IN, Bär-Gilissen MJ, Bak RPM, Cappenberg TE (1994) Rates of benthic protozoan grazing on free and attached sediment bacteria measured with fluorescently stained sediment. Appl environ Microbiol 60:2259-2264

Visscher PT, Beukema J, van Gemerden H (1991) In situ characterization of sediments: measurements of oxygen and sulfide profiles with a novel combined needle electrode. Limnol Oceanogr 36:1476-1480

Manuscript first received: May 29, 1995

Revised version accepted: October 14, 1995 